\title{
Universiteit
}

Leiden

The Netherlands

\section{Ruim baan? Uitsluiting en zelfuitsluiting van de arbeidsmarkt}

Zand, E.G. van 't

\section{Citation}

Zand, E. G. van 't. (2018). Ruim baan? Uitsluiting en zelfuitsluiting van de arbeidsmarkt. Justitiële Verkenningen, 44(2), 117-132.

doi:10.5553/JV/016758502018044002009

Version: Publisher's Version

License: $\quad$ Leiden University Non-exclusive license

Downloaded from: $\quad$ https://hdl.handle.net/1887/67463

Note: To cite this publication please use the final published version (if applicable). 


\title{
Ruim baan? Uitsluiting en zelfuitsluiting van de arbeidsmarkt
}

\author{
Elina van 't Zand-Kurtovic"
}

De afgelopen decennia lijken preventieve maatregelen een vlucht te hebben genomen (Garland 2001; Schuilenburg \& Van Steden 2014), getuige ook de diverse maatregelen die elders in dit nummer aan de orde zijn gesteld. Deze ontwikkeling is duidelijk zichtbaar in het preventief screenen op de arbeidsmarkt. Niet alleen neemt het aantal personen dat aan een integriteitsscreening wordt onderworpen jaarlijks toe, ook wordt naar aanleiding van incidenten nieuw beleid geïntroduceerd waarmee bepaalde groepen personen (zoals zedendelinquenten of terrorismeverdachten) of bepaalde beroepsgroepen (zoals de kinderopvang) als bijzonder risicovol worden beschouwd, met als gevolg dat arbeidsmarktkansen van ex-veroordeelden worden ingeperkt. Het screeningsinstrument Verklaring Omtrent het Gedrag (VOG) maakt het mogelijk iedere (potentiële) werknemer te screenen op justitiële antecedenten. Indien sprake is van een recent (dan wel zeer ernstig) strafrechtelijk verleden, kan een VOG worden geweigerd. In de praktijk blijkt dit preventieve screeningsinstrument breed te worden ingezet en tevens elk jaar aan populariteit te winnen. Zo is in 2017 het aantal aanvragen voor een VOG voor het eerst de grens van 1 miljoen gepasseerd. ${ }^{1}$ Dit is een vermenigvuldiging van bijna acht keer ten opzichte van 2004, toen niet meer dan 136.000 VOG's werden aangevraagd (Kurtovic 2012b). Gezien het tempo waarmee deze vorm van preventief screenen zich elk jaar uitbreidt, is het opmerkelijk dat er tot voor kort (Kruize \& Gruter 2016; Van 't Zand-Kurtovic 2017) nauwelijks empirisch onderzoek is gedaan naar de achtergronden van de zich sterk ontwikkelende populariteit van deze integriteitsscreening en de gevolgen hiervan voor personen met een strafblad. In deze bij-

* Dr. mr. E.G. van 't Zand-Kurtovic is als universitair docent Criminologie verbonden aan de Universiteit Leiden.

1 Zie www.justis.nl/binaries/Kwartaalcijfers\%20Verklaring\%20Omtrent $\% 20$ het $\% 20$ Gedrag \%20(VOG)\%202017_tcm34-304771.pdf. 
drage beschrijf ik een deel van de bevindingen van het promotieonderzoek dat ik tussen 2013 en 2017 uitvoerde naar de impact van het hebben van een strafblad op de re-integratie van jongvolwassenen op de arbeidsmarkt. Om deze impact in het alledaagse leven van jongvolwassenen met een justitieverleden te kunnen duiden, worden ten eerste maatschappelijke ontwikkelingen rondom de VOG besproken en wordt vervolgens het juridisch kader uiteengezet.

\section{Integriteitsbescherming door de overheid}

In 2001 beschrijft Garland in zijn boek The culture of control een aantal ontwikkelingen dat sinds de jaren tachtig in het penologische landschap zichtbaar is. Een daarvan is de afbrokkeling van het rehabilitatie-ideaal. Tegelijkertijd zien we het ontstaan van een geheel nieuwe infrastructuur van preventieve maatregelen die gericht zijn op het voorkomen van risico's en het verhogen van veiligheid op lokaal niveau. Boutellier spreekt in dit verband over een 'veiligheidscomplex', nu sinds de jaren negentig criminaliteit in Nederland onderdeel is geworden van een 'veel groter complex dan het justitiële apparaat; een complex dat zich mentaal en institutioneel organiseert rond dat ene begrip: veiligheid' (Boutellier 2005, p. ix). De hieruit voortvloeiende preventive partnerships (Garland 2001, p. 17) hebben in Nederland vaak een bestuursrechtelijke of civielrechtelijke inbedding (Schuilenburg \& Van Steden 2014; Boone \& Kurtovic 2015, 2016). De toename van integriteitsscreeningen is in dit licht te duiden. Hierbij lijkt zich een verschuiving van straf- naar bestuursrecht te hebben voorgedaan, nu de bijkomende straf van ontzetting uit het beroep of ambt ex artikel 28 van het Wetboek van Strafrecht (Sr) zelden worden opgelegd, ${ }^{2}$ terwijl de VOG-screening jaarlijks sterk groeit. Uit onderzoek onder rechters en officieren van justitie komt het beeld naar voren dat kennis omtrent de mogelijkheden die de strafrechtelijke ontzetting biedt, beperkt is en weinig leeft (Malsch e.a. 2009). Zij lijken zich daarentegen meer bewust te zijn van de mogelijkheden die de VOG biedt en dit instrument bijgevolg een meer prominente rol toe te kennen bij het voorkomen van recidive (Malsch e.a. 2009). 
Het veiligheidsdenken en de ontwikkeling van een risicocultuur in de jaren negentig (De Graaf 2013) leidden voorts mede tot wat door Garland (2001) wordt beschreven als een verschuiving van de focus op bescherming tegen de overheid (d.w.z. machtsmisbruik door de overheid) naar bescherming door de overheid (d.w.z. het monitoren van gevaarlijke groepen). Door deze beschermingsgedachte werd het waarborgen van 'integriteit' meer en meer een taak van de overheid. Het integriteitsbeleid richtte zich vanaf dat moment in toenemende mate op het beschermen van kwetsbare groepen in de samenleving, onder andere door personeel dat met kwetsbare personen werkt - zoals onderwijzers, hulpverleners en verzorgers - vaker preventief te screenen (De Graaf e.a. 2015). Zodoende zette de wetgever in de jaren negentig in op het versterken van het VOG-instrument door in de in 2004 in werking getreden Wet justitiële en strafvorderlijke gegevens (Wjsg) een belangrijker plaats toe te kennen aan de VOG met het oog op criminaliteitspreventie. ${ }^{3}$ In deze doelstelling paste het wijzigen van een afhandeling van VOG-aanvragen op gemeenteniveau naar een centrale afhandeling hiervan door screeningsautoriteit Justis, een uitvoeringsinstantie van het ministerie van Justitie en Veiligheid. ${ }^{4}$

Versterking van het VOG-instrument werd tevens bewerkstelligd door in de VOG-beleidsregels ${ }^{5}$ op te nemen dat een onderzoek naar het gedrag van de aanvrager in ieder geval noodzakelijk is indien het doel van de VOG-aanvraag ziet op het bestendigen dan wel aangaan van een al dan niet betaalde werkrelatie. ${ }^{6}$ Aldus is een integriteitsscreening voor elke vorm van werkrelatie mogelijk en wordt geen drempel opgeworpen wat betreft het type functie waarin van de werknemer een zekere mate van integriteit wordt verwacht. Aan een vuilnisman, vakkenvuller, schoonmaker, hovenier of koerier kunnen dezelfde integriteitseisen worden gesteld als aan een leraar, verpleegkundige, arts, advocaat of politiek ambtsdrager. Personen met een recent justitieel verleden kunnen dus in potentie van de uitoefening van elk soort beroep tijdelijk worden uitgesloten. In de memorie van toelichting schreef de toenmalige minister van Justitie Sorgdrager het niet nodig te achten een ontvankelijkheidstoets in stand te houden ten aanzien van het soort functies waarvoor een integriteitsscreening kan worden

3 Kamerstukken // 1995/96, 24797, 3, p. 5.

4 Stcrt. 2004, 63.

5 Beleidsregels VOG-NP-RP 2004, Stcrt. 2004, 63.

6 Par. 2.1 beleidsregels, Stcrt. 2004, 63. 
verricht. Zij achtte de behoefte van werkgevers aan inzicht in het justitiële verleden van een potentiële werknemer in de meeste gevallen gerechtvaardigd. ${ }^{7}$

Zodoende kan sinds 2004 iedere werkgever, maar ook iedere stageaanbieder, vrijwilligersorganisatie, sport- of hobbyclub én opleiding om een VOG vragen, aangezien het volgens de toenmalige minister 'niet voorstelbaar is dat om een verklaring omtrent het gedrag wordt gevraagd in die gevallen waarin er geen gerechtvaardigde behoefte aan een integriteitsonderzoek is'. Door geen grenzen te stellen aan de inzet van dit instrument is - volgens een beleidsmedewerker van Justis - elk bedrijfsrisico (hoe beperkt ook) verworden tot een maatschappelijk risico, waarvoor een antecedentenonderzoek moet worden opgetuigd (Boone 2012).

\section{Ontwikkelingen en beoordeling van de VOG}

Bij het beoordelen van een VOG-aanvraag worden terugkijktermijnen in acht genomen. ${ }^{8}$ De standaardterugkijktermijn bedraagt vier jaren. Voor jongeren tot 23 jaar is in 2013 een uitzonderingspositie gecreëerd: voor hen geldt een terugkijktermijn van twee jaren, mits zij niet zijn veroordeeld voor - of verdacht worden van - een zedendelict, een misdrijf dat betrekking heeft op terrorisme ${ }^{9}$ of een ernstig geweldsdelict waarop meer dan zes jaar gevangenisstraf staat. Voor zedendelicten geldt dat de terugkijktermijn niet in duur is beperkt. Tot slot gelden voor sommige beroepen afwijkende terugkijktermijnen, ${ }^{10}$ bijvoorbeeld van vijf jaren voor taxichauffeurs, van tien jaren voor buitengewoon opsporingsambtenaren (boa's) en van dertig jaren voor personeel van een justitiële inrichting. ${ }^{11}$

In sommige sectoren wordt bovendien continu gescreend, ${ }^{12}$ wat inhoudt dat zodra ten aanzien van een werknemer een verdenking van een strafbaar feit in de justitiële documentatie wordt geregistreerd, de desbetreffende toezichthouder een melding krijgt en deze kan beslui-

7 Kamerstukken I/ 1995/96, 24797, 3, p. 3.

8 Par. 3.1 beleidsregels.

9 Als bedoeld in art. 83 en $83 \mathrm{~b} \mathrm{Sr}$.

10 Par. 3.1.1, onderdeel b, beleidsregels.

11 Zie voor een overzicht www.justis.nl/producten/vog/vog-aanvragen/naar-welke-gegevenswordt-gekeken/terugkijktermijnen.aspx.

12 Par. 2.2 beleidsregels. 
ten de betrokkene een nieuwe VOG-aanvraag te laten doen. Deze continue screening geldt sinds 2011 in de taxibranche en sinds 2013 in de kinderopvang. Er is een wet in de maak deze vorm van screenen uit te breiden naar luchtvaartpersoneel. ${ }^{13} \mathrm{Na}$ het instellen van een dergelijke vorm van screening is het zaak vast te stellen hoever deze dient te reiken. Zo is in het op 1 maart 2018 in werking getreden personenregister kinderopvang getracht personen die nog buiten het systeem vielen onder de reikwijdte van de continue screening te brengen. Zo is continue screening tegenwoordig ook verplicht voor aannemers die meer dan twee weken op een kinderopvanglocatie aan het werk zijn en voor bijvoorbeeld een gastouder die wekelijks over de vloer komt voor een kopje koffie. ${ }^{14}$ Een andere ontwikkeling is dat de VOG kan worden verlangd van potentiële huurders die in bepaalde (probleem)gebieden willen komen wonen, dit ter beperking van overlast en criminaliteit. ${ }^{15}$ Tot slot wordt een wetsvoorstel voorbereid dat het mogelijk moet maken een VOG enkel op basis van politiegegevens af te wijzen. ${ }^{16}$ Daarvoor is nu nog een registratie in het Justitiële Documentatiesysteem (JDS) nodig. Voor bepaalde beroepen die een hoge mate van integriteit vereisen, zoals functies bij de Dienst Justitiële Inrichtingen en het Openbaar Ministerie en boa's, kan in de toekomst mogelijk op basis van registratie in de politiesystemen worden geconcludeerd dat een persoon niet van onbesproken gedrag is.

Hoe nu vindt de beoordeling van VOG-aanvragen concreet plaats? Ten eerste wordt vastgesteld of er een relatie is tussen het gepleegde delict en de beoogde functie. ${ }^{17}$

13 Kamerstukken // 2015/16, 34501, 3 en 4.

14 Stcrt. 2018, 6054.

15 Dit op grond van de op 1 januari 2017 gewijzigde Wet bijzondere maatregelen grootstedelijke problematiek (Wbmgp), gericht op verbeteren van de leefbaarheid in stedelijke gebieden met een opeenstapeling van problemen. In art. 5 staat geregeld dat, ter beperking van overlast en criminaliteit, de burgemeester kan besluiten geen huisvestingsvergunning te verlenen indien geen VOG kan worden overgelegd.

16 Concept-wetsvoorstel tot wijziging van de Wet justitiële en strafvorderlijke gegevens in verband met het mogelijk maken van het in bepaalde gevallen weigeren van afgifte van een verklaring omtrent het gedrag op basis van politiegegevens van 7 maart 2017.

17 Het objectieve criterium, par. 3.2 beleidsregels. 
Indien dit het geval is, wordt gekeken naar hoe ernstig het risico is, aan de hand van vier wegingsfactoren: ${ }^{18}$

1. de hoeveelheid antecedenten;

2. de afdoening van de strafzaak; ${ }^{19}$

3. het tijdsverloop (in het licht van de terugkijktermijn);

4. de minderjarige ten tijde van het plegen van het delict.

Als deze omstandigheden van het geval in het voordeel van de aanvrager meewegen, wordt de VOG alsnog afgegeven. ${ }^{20}$ Als de VOG-aanvraag wordt afgewezen, heeft de aanvrager in de bestuursrechtelijke procedure die volgt (zienswijze, bezwaar, beroep, hoger beroep) de kans op onderbouwde wijze aan te tonen dat de weging van deze factoren in zijn of haar voordeel dient uit te vallen. ${ }^{21}$ Ook dient de aanvrager te onderbouwen welk belang hij of zij heeft bij afgifte van de VOG en welke ontwikkelingen hij of zij sinds het (laatst gepleegde) delict heeft doorgemaakt, aangezien het belang van de aanvrager uiteindelijk zal worden afgewogen tegen het belang van beschermen van de samenleving (Wildemors 2012). Aldus wordt een totaalinschatting gemaakt van het risico voor de samenleving en of dit laag genoeg is om de VOG af te geven. In figuur 1 is de beoordeling schematisch weergegeven.

\section{Figuur 1 Beoordeling VOG}

- De terugkijktermijn (afhankelijk van type functie of delict)

- De feit/functie-relatie

- Algemene risicoinschatting: afwegen persoonlijke belangen aanvrager tegen belang beschermen samenleving

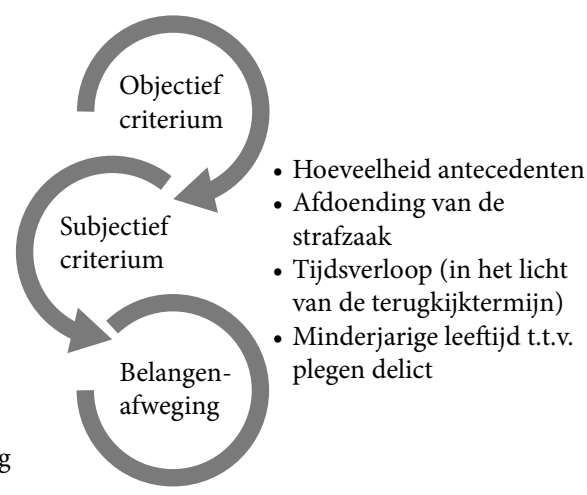

18 Het subjectieve criterium, par. 3.3 beleidsregels.

19 Zie voor een analyse van hoe de afdoening van de strafzaak in de bestuursrechtelijke afweging een rol speelt en vice versa Kurtovic \& Rijnsburger 2016.

20 Zie voor een analyse van deze beoordelingswijze Boone 2012.

21 Zie voor een beschrijving van enige casuïstiek Kurtovic 2015. 


\section{Onzichtbare obstakels op de arbeidsmarkt}

In mijn promotieonderzoek heb ik in kaart proberen te brengen welke obstakels jongvolwassenen vanwege hun strafblad in de praktijk tegenkomen bij het aangaan van een werkrelatie of het volgen van een opleiding. Daartoe zijn 31 jongvolwassenen met een strafblad (gemiddeld 24 jaar oud) over een periode van ongeveer zes tot achttien maanden gevolgd in hun re-integratieproces door middel van diepteinterviews (zowel aan het begin als aan het einde van deze periode), observaties en informele gesprekken. Tevens werden professionals en ouders die bij het re-integratieproces van deze jongvolwassenen betrokken waren, geïnterviewd (38 in totaal).

Allereerst viel op dat jongvolwassenen niet goed weten welke informatie hun 'strafblad' bevat. Een veelvoorkomend misverstand is dat alleen ernstige delicten (waarbij sprake was van geweld of waarop detentie is gevolgd) worden geregistreerd. Sommige jongeren hebben geen idee op welke wijze en voor hoelang er gevolgen kunnen worden verbonden aan het hebben van een strafblad en worden hier dan plotseling mee geconfronteerd op het moment dat een afwijzing van hun VOG op de deurmat valt. Andere jongeren gaan echter van het tegenovergestelde uit: 'Eén ding weet ik zeker: als je eenmaal een strafblad hebt in Nederland, kom je er nooit meer vanaf' (Zaid, 22 jaar). In zekere zin klopt die verklaring, aangezien de bewaartermijnen voor justitiële gegevens zeer lang zijn. ${ }^{22}$ Hoewel voor het verkrijgen van een VOG een veel kortere terugkijktermijn geldt, ervaren veel jongeren de vier jaar die ze moeten wachten voordat het laatst gepleegde delict buiten de terugkijktermijn valt, als een lange periode om 'uit te zitten'. Een van hen vroeg letterlijk - daarmee min of meer een vergelijking trekkend met het uitzitten van een gevangenisstraf: 'Kan je voor mij kijken wanneer mijn tijd erop zit?' (Ajouad, 21 jaar). Wat de jongvolwassenen doorgaans evenmin weten is dat de terugkijktermijn pas gaat lopen op het moment van veroordeling en niet al vanaf het laatst gepleegde delict. Tussen de pleegdatum en de veroordelingsdatum

22 Volgens art. 4 Wjsg worden van misdrijven waarvoor een strafmaximum van minder dan zes jaar geldt de gegevens na twintig jaar verwijderd. Van misdrijven waarop een maximumgevangenisstraf van zes jaar of meer is gesteld, worden de gegevens pas dertig jaar na de einduitspraak uit de justitiële documentatie verwijderd. Gegevens betreffende zedenmisdrijven, bedoeld in art. $240 \mathrm{~b}$ t/m $250 \mathrm{Sr}$, worden na tachtig jaar vernietigd. Registraties ten aanzien van overtredingen worden eerder vernietigd, namelijk na tien jaar indien een vrijheidsstraf of een taakstraf is opgelegd en na vijf jaar in andere gevallen (art. 6 Wjsg). 
kan echter wel een tot twee jaar verstrijken. Jongvolwassenen die proberen een stabiel leven op te bouwen en (op een legale manier) in hun eigen levensonderhoud te voorzien, ervaren dat als een lange tijd.

'Ik dacht: ik krijg gewoon dat blaadje [de VOG; EZ]. Maar eerst krijg je zo'n ding van dat je in bezwaar kan gaan. Ik wist niet wat de procedure was, dus heb ik het maar gelaten voor wat het is. (...) Het moest bij mij zelfs nog bezinken: ik heb een strafblad. (...) Toen ging ik eigenlijk nog meer in zelfmedelijden zitten.' (Delano, 22 jaar)

De onbekendheid met wat er wanneer in de justitiële documentatie wordt geregistreerd en op welke wijze en voor hoelang dit vervolgens een rol speelt in een VOG-procedure, leidt tot het ervaren van een diepe onzekerheid met betrekking tot de bijkomende gevolgen van strafoplegging die mogelijk op de loer liggen. Deze gevolgen kunnen namelijk onverwachts de kop opsteken nadat de jongvolwassenen reeds een werkrelatie zijn aangegaan. De respondent uit het bovengenoemde voorbeeld had er geen benul van dat hij een strafblad had (hij had tweemaal een taakstraf gekregen), dus toen hij de afwijzing van zijn VOG-aanvraag ontving, vormde dat voor hem een pijnlijke confrontatie, temeer omdat hij besefte dat hij zijn baan vaarwel zou moeten zeggen. Op de vraag of hij hierover in gesprek is gegaan met zijn werkgever, reageerde hij: 'No, no! Ik schaamde me gewoon. Letterlijk. (...) Ik heb gewoon een strafblad. Het is een rare redenering gewoon. Je kan er gewoon niks aan doen.'

Het VOG-beleid sluit de mogelijkheid uit dat iemand op voorhand een VOG kan aanvragen: de werkgever moet het aanvraagformulier invullen, aangeven op welke functieaspecten gescreend moet worden, en het vervolgens ondertekenen. Jongvolwassenen zullen dus doorgaans eerst zijn aangenomen voor de baan - en met enige regelmaat ook al aan het werk zijn - voordat het aanvraagformulier kan worden ingediend.

'Ik ben ook een keer aangenomen bij de TNT, pakkettendienst. Zij zeiden: "VOG, waar blijft het?" Ik heb het zo lang mogelijk volgehouden om hem niet af te geven. Zodat ik toch een paar centjes mee kon pikken. Dus ik heb ze dik drie weken laten wachten. En toen op een gegeven moment hield het op, was het over.' (Bryan, 27 jaar) 
De onzekerheid die dit proces teweegbrengt, wordt vergroot doordat iedere werkgever in beginsel een integriteitsscreening kan laten uitvoeren. Bovendien kan het lang duren voordat er zekerheid is of wel of geen VOG kan worden verkregen, doordat het doorlopen van een zienswijze- en bezwaarprocedure gemiddeld ongeveer vijf maanden in beslag neemt. ${ }^{23}$ Hierdoor is het voor hen onmogelijk op voorhand uit te sluiten dat (na het aangaan van een baan) het VOG-vereiste ineens om de hoek komt kijken.

'Je durft sowieso niet overal naar te solliciteren. Je kijkt gelijk of ze om een VOG vragen. (...) Ik keek altijd naar het voorblad en de functie-eisen. Ze vermelden dit alleen niet allemaal en soms ben je het toch later verplicht.

(...) Ook als je bezig bent met sollicitaties en ze nodigen je uit, ben je bang dat ze vragen om een VOG. Dat wordt dan ook je drempel om te gaan solliciteren, die is dan enorm hoog.' (Sabia, 26 jaar)

$\mathrm{Nu}$ het voor jongvolwassenen vaak onbekend is of er, en zo ja welke, bijkomende gevolgen kleven aan een eerdere veroordeling, kan worden gesproken van een 'onzichtbare straf', dan wel in ieder geval van 'onzichtbare obstakels' in hun re-integratieproces. De onzekerheid die dit creëert, belemmert hen namelijk zeer in hun bewegingsvrijheid op de arbeidsmarkt. Zij noemen geregeld dit te ervaren als een 'dubbele straf'.

Van de jongvolwassenen zegt ongeveer twee derde te maken te hebben gehad met uitsluiting van werk naar aanleiding van een antecedentenonderzoek. Dit betrof zowel jongeren met een ernstig strafblad (een detentieverleden) als jongeren met een licht strafblad (zonder detentieverleden en twee tot drie delicten op hun naam). De uitsluiting had vaak betrekking op beroepen waarvoor een VOG wettelijk verplicht is, zoals taxichauffeur. Ook veiligheidsonderzoeken (uitgevoerd door de AIVD) voor het werken op luchthavens, of in een enkel geval een lokale vergunning voor horecaleidinggevende, waren vormen van screeningen waar de jongvolwassenen mee te maken kregen. Daarnaast is screening vaak vereist om als koerier te werken, eveneens een beroep waarin de jongvolwassenen met de VOG te maken krijgen.

23 De wettelijke termijn voor het beslissen op een aanvraag bedraagt acht weken, waarna de bezwaarfase start. Volgens Kruize en Gruter (2016) streeft Justis ernaar 'minstens 75 procent van deze bezwaren binnen twaalf weken vanaf de aanvraag af te handelen en minstens 95 procent binnen achttien weken'. 
Ongeveer een kwart van hen had te maken met uitsluiting van een opleiding, vooral de opleiding tot maatschappelijk werker en de vooropleiding voor Defensie.

\section{Zelfuitsluiting en arbeidsmarktpositie}

In de afgelopen jaren is reeds met enige regelmaat gewezen op het zelfuitsluitende effect van preventief screenen (zie o.a. Vermaas 2015, p. 30; Kurtovic 2015; Gosliga 2015; Kruize \& Gruter 2016). In tegenstelling tot wat doorgaans uit beleidsbrieven van het ministerie van Justitie en Veiligheid naar voren komt, ${ }^{24}$ blijkt uit mijn promotieonderzoek dat het vaak niet alleen om geanticipeerde (verwachte) uitsluiting gaat, maar dat veel jongeren ook daadwerkelijk zelf reacties van uitsluiting hebben ervaren tijdens hun re-integratieproces. De VOG vormt voor hen een plotseling obstakel op de weg van re-integratie, en zij weten onvoldoende wanneer en hoe zij dit kunnen overwinnen. Hierbij komen allerlei negatieve emoties, zoals frustratie, terneergeslagenheid, angst, schaamte en demotivatie om de hoek kijken.

'Ik heb geen school meer gedaan. Je raakt gedemotiveerd en denkt: ik word toch niet aangenomen.' (Abdel, 20 jaar)

'M'n VOG die weer was afgewezen en ja, weet je, was gewoon kut. Was gewoon zwaar kut. (...) Beetje bittere pil. Dat ik m'n VOG niet heb gekregen. Beetje wel. Toch wel stiekem op gehoopt. Is niet alsof ik hem echt verdien, dat weet ik ook wel. Ik ga niet kwaad worden als ik weet dat ik zelf fouten heb gemaakt. (...) Schaamtegevoel kreeg ik heel erg. Uitgekotst worden door de maatschappij. Uitgekotst worden door iedereen om jou heen. Niemand die jou wil helpen en het gevoel dat je er alleen voor staat. En woede in mij. Ik was zo kwaad. (...) Maar maakt me allemaal niet meer uit. Anders word ik teleurgesteld. Wil niet weer iets waar ik me zo negatief over ga voelen. Het is meer van dag tot dag.' (Milad, 21 jaar)

De verhalen van de jongvolwassenen hebben aldus een belangrijke dynamiek blootgelegd die voortkomt uit een steeds verder uitdijend systeem van preventief screenen voor toegang tot banen en zelfs tot opleidingen, namelijk zelfuitsluiting. 
Voor de jongvolwassenen is het vooral onduidelijk wanneer er voldoende tijd is verstreken op basis waarvan het door hen getoonde positieve gedrag op waarde wordt geschat. Uit de verhalen van de jongvolwassenen blijkt bovendien dat re-integratieprofessionals hierin een ambivalente rol spelen. Zij ervaren niet altijd voldoende steun van hun begeleiders als het gaat om het managen van verwachtingen en hoe zij kunnen omgaan met processen van stigmatisering. Veel jongeren hebben er bijgevolg wel eens voor gekozen zichzelf - op voorhand - uit te sluiten van werk of opleiding, uit angst door een werkgever of school persoonlijk de deur te zullen worden gewezen. Persoonlijke afwijzing is wat zij koste wat kost willen voorkomen.

'Die angst dat ik hem nu niet krijg beheerst echt alles. Maar ik wil de eer aan mezelf houden. (...) Dus ik ga liever uit mezelf weg dan eerlijk te zeggen wat er is gebeurd en dan alsnog eruit moet.' (Sabia, 26 jaar)

Uit hun verhalen blijkt dat zij zich er wel van bewust zijn dat de beperkingen op de arbeidsmarkt hooguit voor een bepaalde periode gelden, maar dat zij niet weten hoelang dit exact duurt (bijvoorbeeld dat bij de terugkijktermijn de datum van veroordeling wordt gehanteerd). Om die reden kunnen zij onverwachts tegen beperkingen aanlopen. Bovendien ervaren zij, ook al begrijpen zij dat een VOG niet voor alle beroepen wordt gevraagd, toch grote moeilijkheden tijdens het proces van zoeken naar werk. Dit gebeurt bijvoorbeeld wanneer de VOG-vereiste niet reeds in de vacaturetekst of tijdens het sollicitatiegesprek wordt vermeld, maar als een formaliteit wordt beschouwd die moet worden afgehandeld zodra iemand aan de slag is gegaan.

'Je krijgt twee selectierondes. Heb ik allemaal goed doorlopen. Ben ik aangenomen. Maar toen kwam het, toen zeiden ze tegen mij: of ik nog even langs het gemeentehuis wilde gaan en een VOG ophalen. Toen heb ik gezegd: doe ik. Maar ik wist natuurlijk: ik ga het niet krijgen. Sindsdien heb ik niks meer van me laten horen, want ik wist: dat gaat toch niks worden.

Ga ik niet krijgen.' (Oussama, 29 jaar)

Veel van de jongvolwassenen vermijden daarom nog liever te solliciteren naar een baan dan dat zij naderhand geconfronteerd worden met persoonlijke afwijzing en hun baan noodgedwongen moeten verlaten. Als zij wel een baan hebben gevonden waarbij het strafblad of de VOG 
niet aan de orde kwam, beschouwen zij dit als 'geluk hebben' (Yushua, 26 jaar).

Een deel van de jongvolwassenen blijkt erg gevoelig te zijn voor negatieve, stigmatiserende sociale reacties en internaliseert deze, waarna zij negatief over zichzelf gaan denken ('niemand wil me hebben', 'ik word nergens geaccepteerd'). Soms accepteren zij dat ze geen nieuwe kans lijken te verdienen, waardoor hun motivatie en hoop voor de toekomst verdwijnen ('ik heb de hoop min of meer opgegeven', 'ik word toch weer teleurgesteld'). Vanwege hun ervaringen met uitsluiting van werk en ook vanwege zelfuitsluiting blijkt het voor veel jongvolwassenen een strijd om gemotiveerd te blijven in het proces van werk zoeken. Zij ervaren vaak dat de enige banen die zij kunnen krijgen banen zijn die 'niemand anders wil' en die geen toekomstperspectief bieden, bijvoorbeeld omdat alleen tijdelijke contracten worden geboden. $\mathrm{Zij}$ komen dus wel ergens aan de bak, maar zeker niet op een positie die hun voldoening geeft dan wel de stabiliteit biedt die zij zo hard nodig hebben om een bestendige toekomst op te bouwen.

\section{Discussie}

Recapitulerend is in deze bijdrage aandacht besteed aan de vlucht die preventieve screeningsmaatregelen, in het bijzonder de VOG, in de afgelopen decennia hebben genomen als gevolg van een nadruk op bescherming tegen risico's door de overheid. Met het wegvallen van de ontvankelijkheidstoets voor VOG-aanvragen werd het vanaf 2004 zonder meer mogelijk voor elke (on)betaalde werkrelatie een potentiële werknemer, vrijwilliger, stagiair of student aan een antecedentenscreening te onderwerpen. De dreiging die hiervan uitgaat voor personen met een justitieel verleden, namelijk dat zij tijdens hun zoektocht naar werk onverwachts op afwijzing en uitsluiting stuiten, is bijgevolg voor alle functies, taken of bezigheden in beginsel aanwezig. $\mathrm{Al}$ is deze mogelijke uitsluiting op grond van de VOG-beleidsregels officieel aan termijnen gebonden (doorgaans vier jaar), toch is er over het algemeen weinig bekendheid met de exacte lengte ervan, evenals het moment waarop deze termijn gaat lopen, zo blijkt uit de verhalen van de 31 jongvolwassenen die participeerden in mijn empirisch onderzoek. De reacties van uitsluiting van de arbeidsmarkt die zij ervaren blijken dusdanig veel negatieve impact te hebben, dat zij vervolgens 
lange tijd vermijden te solliciteren naar banen als zij vermoeden daarvoor een VOG nodig te hebben, waardoor zij in een onzekere arbeidsmarktpositie verkeren. Op basis van het longitudinale, kwalitatieve onderzoek dat ik onder deze jongvolwassenen verrichtte, kan aldus worden vastgesteld dat zelfuitsluiting een niet te onderschatten effect van deze maatregel is.

Voor jongvolwassenen met een relatief beperkt strafblad, die zich mogelijk te snel of te lang onterecht uitsluiten van de arbeidsmarkt, zou het optuigen van voorlichtingscampagnes wellicht helpen. Hierop zet het ministerie momenteel sterk in (met o.a. een filmclip en website), vanwege het idee dat 'zowel jongeren als hun begeleiders de kansen op het krijgen van een VOG te laag inschatten'. ${ }^{25}$ De vraag is echter wat er dient te gebeuren met jongvolwassenen die een relatief ernstig strafblad hebben en er daarom in de meeste gevallen terecht van uitgaan dat zij de eerstkomende jaren na detentie moeilijk aan een baan zullen komen. Dit onderzoek toont aan waarom het verwijzen naar de officiële afwijzingspercentages van de VOG (onder het mom van 'als je een VOG aanvraagt, dan krijg je die in 99\% van de gevallen wel'26) niet volstaat. Wie enkele niet al te zware delicten op zijn naam heeft staan, maakt binnen de terugkijktermijn welllicht kans toch een VOG te verkrijgen op grond van zijn of haar positieve ontwikkeling (Kurtovic 2012a, 2015). Dit wordt echter lastig wanneer de aanvrager lange tijd in detentie heeft gezeten, terwijl die groep juist het meeste baat heeft bij een voorspoedige re-integratie. Daarom is vervolgonderzoek nodig naar de omvang van zelfuitsluitingsprocessen. ${ }^{27}$ De focus van beleidsmakers lijkt vooral te liggen op jongeren met doorgaans enkele delicten op hun naam, gepleegd uit zogeheten 'jeugdige onbezonnenheid', terwijl juist in het kader van succesvolle re-integratie (en daarmee het voorkomen van recidive) aan zwaardere delinquenten aandacht dient te worden besteed.

Gebleken is dat de jongvolwassenen persoonlijke afwijzing - nadat zij ergens zijn aangenomen - koste wat kost willen vermijden, en daardoor kansen mislopen. Als gevolg van deze dynamiek van zelfuitsluiting of 'zelfcensuur' (Kruize \& Gruter 2016) zou het bevorderen van

25 Kamerstukken // 2016/17, 34550 VI, 98, p. 3.

26 Zo staat op de website voor jongeren te lezen: 'In 2016 kreeg meer dan 99\% van de jongeren die een VOG aanvroegen deze ook. Heel veel dus!', zie https://watdevog.nl/\#vog-faqs.

27 Het ministerie heeft reeds opdracht gegeven het dark number in kaart te brengen van zogeheten 'VOG-vermijders' onder jongeren die een mbo-opleiding willen gaan volgen, zie Kamerstukken I/ 2015/16, 34300 IV, 78, p. 2. 
bewustwording onder jongeren over (het bestaan van) de VOG-screening onder het huidige systeem mogelijk zelfs tot minder aanvragen door deze (kwetsbare) doelgroep kunnen leiden. Een groter bewustzijn van de kans gescreend te moeten worden op basis van hun strafblad kan dan leiden tot een toename van het aantal gevallen van zelfuitsluiting. Dit zou een averechts effect sorteren ten opzichte van wat de staatssecretaris met de voorlichtingscampagnes voor jongeren beoogt. Een structurele wijziging in de (bestuursrechtelijke) procedure die geldt voor VOG-aanvragen zou mogelijk uitkomst kunnen bieden, indien aanvragers van tevoren kunnen weten waar zij aan toe zijn. Bovendien zou beleid kunnen worden gecreëerd dat het mogelijk maakt de afgifte van de VOG, in plaats van automatisch en passief, actief en beloninggeoriënteerd in te kleden, ${ }^{28}$ zodat jongvolwassenen naar ontvangst van een VOG - als beloning van positief gedrag - kunnen toewerken, in plaats van het feitelijk vaststellen dat nog sprake is van onvoldoende tijdsverloop om de VOG te kunnen afgeven (Boone 2011). Nu het aantal VOG-aanvragen reeds sinds 2004 elk jaar fors stijgt, dient nader onderzoek aan te tonen in hoeverre voor jongeren en jongvolwassenen daadwerkelijk 'ruim baan' wordt gemaakt.

\section{Literatuur}

\section{Boone 2011}

M. Boone, 'Judicial rehabilitation in the Netherlands: Balancing between safety and privacy', European Journal of Probation (3) 2011, afl. 1, p. 63-78.

\section{Boone 2012}

M. Boone, “'Gestraft” na de straf. Legaliteit en proportionaliteit van juridische belemmeringen na afloop van de straf', PROCES (91) 2012, afl. 2, p. 103-114.

\section{Boone \& Kurtovic 2015}

M.M. Boone \& E.G. Kurtovic, 'Collateral consequences and the principle of proportional punishment', in: F. de Jong, M. Boone, C. Kelk e.a. (red.), Overarching views of crime and deviancy Rethinking the legacy of the Utrecht School, Den Haag: Eleven International Publishers 2015, p. 401-418.

28 Zie voor een discussie over de werking van de VOG als beloning van positief gedrag Kurtovic \& Boone 2017a, 2017b; Kruize e.a. 2017. 


\section{Boone \& Kurtovic 2016}

M.M. Boone \& E.G. Kurtovic, 'Bijkomende gevolgen van straf en het principe van proportionele strafoplegging', Nederlands Juristenblad 2016, afl. 23,

p. 1623-1629.

\section{Boutellier 2005}

H. Boutellier, De veiligheidsutopie. Hedendaags onbehagen en verlangen rond misdaad en straf, Den Haag: Boom Juridische uitgevers 2005 .

\section{Garland 2001}

D. Garland, The culture of control: Crime and social order in contemporary society, Chicago: University of Chicago Press 2001.

\section{Gosliga 2015}

F.P. Gosliga, De stem van de uitvoering in perspectief. Een experimentele verkenning van de beleving van risicojongeren en jeugdprofessionals rond de aanvraag van de VOG, Almere: SenseGuide 2015.

\section{De Graaf 2013}

B. de Graaf, 'Het temmen van de toekomst. Van een veiligheidsnaar een risicocultuur', Tijdschrift over Cultuur \& Criminaliteit (3) 2013, afl. 2, p. 155-172.

\section{De Graaf e.a. 2015}

B. de Graaf, L. van der Heide, P. Blu, S. Lenze \& W. Klem, Integriteit in een veiligheidsklimaat. Naar een afwegingskader voor het toekennen en uitvoeren van overheidsbevoegdheden op het gebied van integriteitsbevordering, Leiden/Den Haag: Universiteit Leiden/Ministerie van Veiligheid en Justitie 2015.

\section{Kruize \& Gruter 2016}

P. Kruize \& P. Gruter, Eens een dief, altijd een dief? Een verkenning rond het meten van de effectiviteit van de Verklaring Omtrent het Gedrag, Den Haag: WODC 2016.

\section{Kruize e.a. 2017}

P. Kruize, P.M.G. Gruter \& H.C.J. van der Veen, 'Onderzoek naar de effectiviteit van de VOG: de resultaten zonder ruis', Strafblad (15) 2017, afl. 5, p. 429-431.

\section{Kurtovic 2012a}

E.G. Kurtovic, 'Jeugdzonde, eeuwig zonde? Een onderzoek naar de beoordelingswijze van Verklaring Omtrent het Gedrag-aanvragen van jongeren', PROCES (91) 2012, afl. 2, p. 115-127.

\section{Kurtovic 2012b}

E.G. Kurtovic, Jeugdzonde, eeuwig zonde? Een onderzoek naar de beoordeling van Verklaring Omtrent het Gedrag aanvragen van jongeren in het licht van resocialisatie (masterscriptie Utrecht), 2012. 


\section{Kurtovic 2015}

E.G. Kurtovic, 'Krijgt mijn kind een strafblad? De Verklaring Omtrent het Gedrag in de praktijk', Tijdschrift Jeugdrecht in de Praktijk 2015, p. 20-25.

\section{Kurtovic \& Boone 2017a}

E.G. Kurtovic \& M.M. Boone, 'De preventieve werking van het VOG-beleid. Kritische kanttekeningen bij "Eens een dief, altijd een dief?"', Strafblad (15) 2017 , afl. 3, p. 272-278.

\section{Kurtovic \& Boone 2017b}

E.G. Kurtovic \& M.M. Boone, 'De effectiviteit van de VOG: alleen in theorie, of ook in de praktijk?', Strafblad (15) 2017, afl. 5, p. 432-433.

\section{Kurtovic \& Rijnsburger 2016}

E.G. Kurtovic \& M.D. Rijnsburger, 'De straf- en bestuursrechter als communicerende vaten in VOGzaken', Delikt en Delinkwent (46) 2016, afl. 9, p. 781-801.

\section{Malsch e.a. 2009}

M. Malsch, W.C. Alberts, J.W. de Keijser \& J.F. Nijboer, Strafrechtelijke ontzetting uit beroep of ambt. Oplegging en naleving in de periode 1995-2008, Den Haag: WODC 2009.

\section{Schuilenburg \& Van Steden 2014}

M. Schuilenburg \& R. van Steden, 'Praktijken van selectieve uitsluiting. Over de bescherming door en tegen veiligheidsassemblages', Cahiers Politiestudies (30) nr. 1 2014, p. 51-62.

\section{Vermaas 2015}

P. Vermaas, 'Vraag die VOG gewoon aan', Opportuun (21) 2015, afl. 1, p. 30.

\section{Wildemors 2012}

R. Wildemors, 'De beoordeling van een VOG-aanvraag', PROCES (91) 2012, afl. 2, p. 82-88.

\section{Van 't Zand-Kurtovic 2017}

E.G. van 't Zand-Kurtovic, Invisible bars. The impact of having a criminal record on young adults' position in the labour market (diss. Utrecht), Den Haag: Eleven International Publishing 2017, https://dspace.library.uu.nl:8443/ handle/1874/357001. 